\title{
Effect of slope position on soil particle-size distribution in young glacial landscape (Lyna River valley, NE Poland)
}

\begin{abstract}
The aim of this paper was to characterize soil particle-size distribution (PSD) of in the middle part of young glacial Łyna River valley in relation to parent materials, soil forming processes and slope position. The study comprised rusty soils, arenosols, clay-illuvial soils, colluvial and alluvial soils located in four slope position: summit / midslope, footslope / toeslope, upper and lower part of floodplain. In order to describe the sedimentological environment and possible heterogenity of the soil formations, sedimentological and granulometric indices were calculated. The relationships between soil fractions in A horizons and environmental variables (slope position and depth of A horizon) were determined using principal component analysis (PCA).

The studied soils were poorly sorted with various values of skewness of granulometric distribution (symmetrical, fine and very fine skewed) and kurtosis (mainly very leptokurtic). The value of mean grain diameter was decreasing with slope position which may suggest high dynamics and energy of sedimentological environment in the middle part of Łyna River valley. The analysis of granulometric indices revealed that colluvial deposits were the most homogenous and alluvial formations were the most heterogenous. The results of the statistical analysis showed a positive correlation of the amounts of clay and silt fractions with depth of A horizons. The factor responsible for variability of these fractions was the position on the slope. The A horizons in soils located at the summit and footslope had the highest amounts of sand fractions. While significant increase in the share of finer fractions in soils located in the floodplain was noted.
\end{abstract}

Keywords: particle-size distribution, sedimentological indices, granulometric indices, slope

\section{INTRODUCTION}

Particle-size distribution (PSD) determines soil quality and use (Prusinkiewicz and Proszek 1990). The PSD influences soil physical (bulk density, porosity, water relations etc.) and chemical (sorptive properties, organic matter composition, content of elements etc.) properties directly and/or indirectly. Based on the quantitative proportions of soil particles of different diameter it is also possible to determine certain soil physical properties (Bittelli et al. 1999, Brogowski 1990, Brogowski et al. 2014, Brogowski and Kwasowski 2014, 2015). Interpretation of the PSD and the use of sedimentological and granulometric indices allow to determine the origin of sedimentary environments of soil formations. This is particularly important when natural lithogenic and pedogenic processes overlap with human-induced processes transforming natural environment (Kabała and Marzec 2010, Smolska 2005, Sowiński 2014, Świtoniak 2014). Therefore, the PSD analysis is commonly used in order to estimate natural and anthropogenic processes of soil erosion and denudation (Zhao et al. 2011). Moreover, the PSD, which is the result of lithogenic and pedogenic processes, is frequently the primary indicator of soil origin and systematic position (Musztyfaga and Kabała 2015, Mycielska-Dowgiałło 1980, Prusinkiewicz and Proszek 1990, Prusinkiewicz et al. 1994, Racinowski et al. 2001, Świtoniak 2015, Zagórski 1996). These analyses may also answer the questions about the degree of soil cover transformation in a given region.

Young glacial river valleys of northern Poland have diverse soil cover. It is related to the nature of accumulated soil parent materials and diversity of soil processes (Jonczak and Kowalkowski 2013, Smólczyński et al. 2013). Particularly noteworthy are the river valleys where the rivers use outwash trails formed as a result of glacifluvial outflow during Vistulian glaciation. Such land forms are surrounded by glacial tills of ground moraine. In the river valley, fluvioglacial as well as alluvial, colluvial and organic deposits were accumulated (Bieniek 2013, GlińskaLewczuk et al. 2014, Piaścik et al. 2004, Sowiński et al. 2016). Mineral deposits in these valleys are characterized by different sedimentary environments (Mycielska-Dowgiałło 1980, Racinowski et al. 2001). In these soils various processes overlap, particularly 
in transition zones of footslopes and floodplains (Booth et al. 2013, Sklar et al. 2016). Individual soil fractions are translocated and accumulated as a result of colluvial and alluvial processes (Smólczyński et al. 2013, Sowiński 2014, Sowiński et al. 2016). It may affect spatial distribution of soils and their properties in young-glacial river valleys.

The aim of this paper was to analyze the effect of slope position on soil particle-size distribution in young glacial Łyna River valley by: (1) vertical and horizontal distribution of soil fractions in four slope positions, (2) determination of sedimentological and granulometric indices, (3) determination of relationship between soil fractions and environmental variables (slope position and depth of A horizon) by using a multivariate method of PCA.

\section{MATERIALS AND METHODS}

The study was carried out in the middle part of the Lyna River valley (Fig. 1), NE Poland at three soil sequences, representing young glacial landscape. The origin of this landscape is related to activity of a glacier in the Pomeranian Phase of the Vistulian glaciation (Pleistocene) as well as melting waters, alluvial and colluvial processes in the Holocene.

Three soil transects in Knopin (A - profiles 1-4), Smolajny (B - profiles 5-11) and Łaniewo ( $\mathrm{C}$ - profiles 1-16) villages were selected (Fig. 1). Analyzed soil profiles were grouped according to their position on the slope: summit / midslope, footslope / toeslope, upper and lower parts of floodplain. More detailed description of the sites was presented in previous papers (Glińska-Lewczuk et al. 2014, Sowiński et al. 2016). In total 49 soil samples from 16 soil profi-

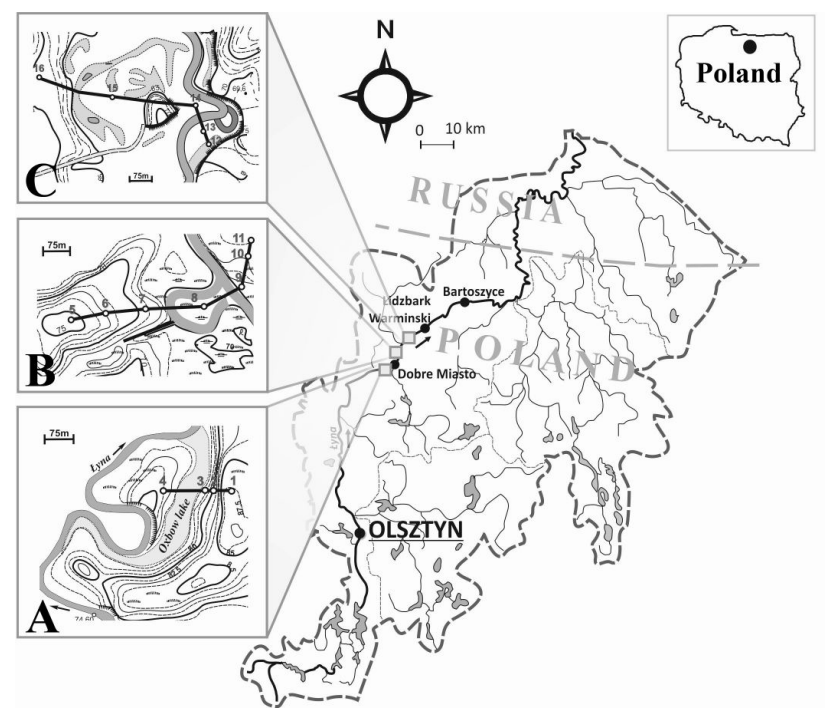

FIGURE 1. Location of soil profiles in transects les were collected from genetic horizons. Particle-size distribution of the fine earths $(<2 \mathrm{~mm})$ was analysed according to hydrometer method of Bouyoucos modified by Cassagrande and Prószyński with the separation of sand sub-fractions by dry sieving (Ryżak et al. 2009). The soil texture classes were determined according to the classification of PTG (2009) and USDA classification system (Schoeneberger et al. 2012). The results of PSD analysis (percentage of fractions) were analyzed with the SIEWCA software (BJB 2010) in order to draw granulometric curves and calculate sedimentological indices according to Folk and Ward (1957). The following indices were used for granulometric analyzes: mean diameter $(\mathrm{Md})$, standard deviation $\left(\mathrm{d}_{1}\right)$, skewness $\left(\mathrm{Sk}_{1}\right)$ and kurtosis $\left(\mathrm{K}_{\mathrm{G}}\right)$. Granulometric indices were also calculated, determining the relative proportions between fractions of bigger diameter (Kowalkowski and Prusinkiewicz 1963). These parameters can be helpful in predicting the initial homogeneity or heterogeneity of soil material. Ratios between soil fractions were calculated $(\phi$ in $\mathrm{mm}$ ) $\mathrm{A}=0.25-0.10 / 0.50-0.25, \mathrm{~B}=0.25-0.10 /$ $1.00-0.50, \mathrm{C}=0.25-0.05 / 0.50-0.25, \mathrm{D}=0.25-0.02 /$ $1.00-0.25, \mathrm{E}=0.50-0.05 / 1.0-0.50$.

The studied soils were classified according to the Polish Soil Classification System (2011) and WRB system (IUSS Working Group WRB 2015).

For the identification of primary environmental gradients affecting particle-size distribution in soils, multivariate statistical analyses involving a linear indirect method of Principal Component Analysis (PCA) was applied using default (standard) options. The data were transformed to $\log$ arithms $\log (\mathrm{n}+1)$ to meet conditions of normality. For the ordination analysis CANOCO 4.5 software was used (ter Braak and Šmilauer 2002).

\section{RESULTS AND DISCUSSION}

\section{Particle-size distribution and soil texture classes}

In the middle part of the Łyna river valley glacial tills, fluvioglacial, alluvial and colluvial deposits occur. It is related to the formation of the valley itself, which uses the Pleistocene outwash trail that was formed during the glacifluvial outflow during the Vistulian glaciation (Bieniek 2013).

The studied soils showed a specific spatial distribution pattern (Table 1). Typical rusty soils (in Polish: gleby rdzawe typowe) and arenosols (in Polish: arenosole) developed from fine and medium sands of fluvioglacial origin (Table 2, Fig. 2) occurred on the summit and midslope. These soils contained minor 
TABLE 1. Systematic position of the studied soils according to PSC 2011 and WRB 2015

\begin{tabular}{|c|c|c|}
\hline Profile No. / land use & PSC 2011 & WRB $2015^{*}$ \\
\hline \multicolumn{3}{|l|}{ Transect A (Knopin) } \\
\hline 1 / grassland & Typical rusty soil (Gleba rdzawa typowa) & Dystric Brunic Arenosol (Ochric, Aric) \\
\hline 2 / grassland & Arenosol (Arenosol) & Dystric Arenosol (Aric, Ochric, Protocalcic) \\
\hline 3 / grassland & Proper colluvial soil (Gleba deluwialna właś ciwa)** & Haplic Umbrisol (Arenic, Colluvic) \\
\hline 4 / grassland & Proper colluvial soil (Gleba deluwialna właś ciwa)** & $\begin{array}{l}\text { Eutric Arenosol (Pantocolluvic, Ochric, } \\
\text { Bathycalcaric) }\end{array}$ \\
\hline \multicolumn{3}{|l|}{ Transect B (Smolajny) } \\
\hline 5 / arable land & Typical clay-illuvial soil (Gleba płowa typowa) & Luvic Phaeozem (Loamic, Aric) \\
\hline $6 /$ arable land & Gleyic clay-illuvial soil (Gleba płowa gruntowo-glejowa) & Luvic Umbrisol (Loamic, Aric, Bathygleic) \\
\hline 7 / arable land & Typical humic colluvial soil (Gleba deluwialna czarnoziemna & Haplic Umbrisol (Loamic, Aric, Colluvic, \\
\hline 8 / grassland & typowa) & Bathygleic) \\
\hline 9 / grassland & Typical humic alluvial soil (Mada czarnoziemna typowa) & Fluvic Phaeozem (Geoabruptic, Loamic) \\
\hline 10 / arable land / fallow & Typical humic alluvial soil (Mada czarnoziemna typowa) & Fluvic Phaeozem (Hyperhumic, Loamic) \\
\hline \multirow[t]{2}{*}{11 / arable land / fallow } & Proper colluvial soil (Gleba deluwialna właś ciwa)** & Eutric Umbrisol (Pantocolluvic) \\
\hline & Arenosol (Arenosol) & Dystric Arenosol (Aric, Ochric, Protocalcic) \\
\hline \multicolumn{3}{|l|}{ Transect C (Łaniewo) } \\
\hline 12 / fallow & Typical alluvial soil (Mada właś ciwa) & Dystric Fluvisol (Loamic) \\
\hline 13 / grassland & Typical humic alluvial soil (Mada czarnoziemna typowa) & Fluvic Phaeozem (Loamic) \\
\hline 14 / grassland & Proper alluvial soil (Mada właś ciwa) & Dystric Fluvisol (Loamic) \\
\hline 15 / grassland & Proper alluvial soil (Mada właś ciwa) & Dystric Fluvisol (Loamic) \\
\hline 16 / arable land & Typical rusty soil (Gleba rdzawa typowa) & Dystric Brunic Arenosol (Ochric, Aric) \\
\hline
\end{tabular}

* according to suggestions by Kabała et al. (2016); ${ }^{* *}$ according to suggestions by Świtoniak (2015).

amounts of clay fraction (up to $2 \%$ ) and more silt fraction $(7 \%$ in average, max $16 \%)$. The fractions of medium and fine sand $(0.5-0.1 \mathrm{~mm})$ prevailed in these soils. Typical and gleyic clay-illuvial soils (in Polish: gleby płowe typowe and gruntowo-glejowe) were formed from glacial till (loam, silt and clay - different texture classes). In A and Et horizons they contained $6-26 \%$ of clay fraction (Table 2, Fig. 2B). The content of the finest fraction increased with depth up to $66 \%$ (profile 6, Cg horizon - Fig. 2A). These soils were also rich in silt fraction - maximum content of $60 \%$ in 5 profiles in Et horizon.

The colluvial soils (in Polish: gleby deluwialne) occurred at footslope and toeslope. The colluvial material had sandy (fine sand and loamy fine sand) texture in profiles 3, 4 and 10. Taking into account the suggestions made by Świtoniak (2015), these soils were classified as a proper colluvial soils (in Polish: gleby deluwialne właściwe), although there is not such soil unit in Polish Soil Classification (2011). The colluvial deposits had also loamy (fine sandy loam) and silty (silt loam) texture in profile 7 . This soil was classified as typical humic colluvial soil (in Polish: gleba deluwialna czarnoziemna typowa). Particle-size distribution of these soils is a derivative of the PSD of eroded soils (Bieniek 1997, Smolska 2005, Sowiński 2014, Sowiński et al 2015). Colluvial soils (profiles $3,4,10$ ), formed as a result of erosion of sandy soils (rusty soils and arenosols), were characterized by fine sand and loamy fine sand texture. They had similar amounts of clay fractions and slightly higher amounts of silt fraction in comparison with eroded soils (Table 2, Fig. 2A, 2C). Colluvic horizons in profile 7 formed in the group of soils with finer texture (clay-illuvial soils) had a texture of fine sandy loam and silt loam. They contained more clay fraction and similar amounts of silt fraction in comparison to A horizons of eroded soils. Analyzing the PSD of colluvial soils in the profiles: 3,4 and 7, the lithological / pedogenic discontinuity was evident.

Glacial and colluvial deposits had sectional structure of cumulative curves (Fig. 2A, 2B, 2C) which suggested high variability of parent material and reflected non river-current specificity of these sedimentological environments. According to Racinowski et al. (2001), fluvioglacial sediments may have 2 or 3 sections in the structure of cumulative curves.

Upper parts of floodplain were covered with typical alluvial soils (in Polish: mady właściwe) developed from alluvial loams in profiles 12,14 and 15 (loam, sandy loam and fine sandy loam texture). Typical alluvial soils occurring in the vicinity of rusty soils had texture of fine sandy loam and sandy loam (Table 2, Fig. 2D). They contained more fine and very fine sand, and significantly more coarse silt (up to $38 \%$ ) and clay fraction (up to 19\%) than the surrounding soils.

Lower parts of the floodplain were occupied by typical humic alluvial soils (in Polish: mady czarnoziemne typowe) developed from loam and silt with 
TABLE 2. Particle-size distribution in the studied soils

\begin{tabular}{|c|c|c|c|c|c|c|c|c|c|c|c|c|c|c|}
\hline \multirow{2}{*}{$\begin{array}{l}\text { Slope } \\
\text { position }\end{array}$} & \multirow{2}{*}{$\begin{array}{l}\text { Profile } \\
\text { No. }\end{array}$} & \multirow[t]{2}{*}{ Horizon } & \multirow{2}{*}{$\begin{array}{l}\text { Depth } \\
\text { (cm) }\end{array}$} & \multicolumn{2}{|c|}{ Texture class } & \multicolumn{9}{|c|}{ Particle-size (mm) distribution (\%) } \\
\hline & & & & PTG & USDA & $>2.0$ & $2.0-1.0$ & $1.0-0.5$ & $0.5-0.25$ & $0.25-0.10$ & $0.10-0.05$ & $0.05-0.02$ & $0.02-0.002$ & $<0.002$ \\
\hline \multirow[t]{6}{*}{$\begin{array}{l}\text { Summit / } \\
\text { midslope }\end{array}$} & 1 & $\begin{array}{l}\text { A } \\
\text { Bv } \\
\text { C }\end{array}$ & $\begin{array}{c}0-26 \\
26-120 \\
120-150\end{array}$ & $\begin{array}{l}\text { ps } \\
\text { ps } \\
\text { pl }\end{array}$ & $\begin{array}{l}\text { FS } \\
\text { FS } \\
\text { FS }\end{array}$ & $\begin{array}{l}0 \\
0 \\
0\end{array}$ & $\begin{array}{l}3 \\
2 \\
4\end{array}$ & $\begin{array}{r}3 \\
5 \\
11\end{array}$ & $\begin{array}{l}12 \\
10 \\
30\end{array}$ & $\begin{array}{l}57 \\
55 \\
50\end{array}$ & $\begin{array}{r}14 \\
16 \\
1\end{array}$ & $\begin{array}{l}5 \\
7 \\
1\end{array}$ & $\begin{array}{l}4 \\
4 \\
2\end{array}$ & $\begin{array}{l}2 \\
1 \\
1\end{array}$ \\
\hline & 16 & $\begin{array}{l}\text { Ap } \\
\text { Bv } \\
\text { C }\end{array}$ & $\begin{array}{l}0-26 \\
26-80 \\
80-150\end{array}$ & $\begin{array}{l}\text { ps } \\
\text { pl } \\
\text { pl }\end{array}$ & $\begin{array}{l}\text { FS } \\
\text { MS } \\
\text { MS }\end{array}$ & $\begin{array}{l}0 \\
0 \\
0\end{array}$ & $\begin{array}{r}7 \\
11 \\
6\end{array}$ & $\begin{array}{l}11 \\
12 \\
15\end{array}$ & $\begin{array}{l}22 \\
35 \\
37\end{array}$ & $\begin{array}{l}40 \\
36 \\
33\end{array}$ & $\begin{array}{l}4 \\
1 \\
1\end{array}$ & $\begin{array}{r}12 \\
1 \\
6\end{array}$ & $\begin{array}{l}4 \\
2 \\
2\end{array}$ & $\begin{array}{l}0 \\
2 \\
0\end{array}$ \\
\hline & 2 & $\begin{array}{l}\mathrm{A} \\
\mathrm{C}\end{array}$ & $\begin{array}{c}0-28 \\
28-150\end{array}$ & $\begin{array}{l}\text { ps } \\
\text { pl }\end{array}$ & $\begin{array}{l}\text { FS } \\
\text { MS }\end{array}$ & $\begin{array}{l}0 \\
0\end{array}$ & $\begin{array}{l}1 \\
8\end{array}$ & $\begin{array}{r}4 \\
15\end{array}$ & $\begin{array}{l}19 \\
45\end{array}$ & $\begin{array}{l}55 \\
31\end{array}$ & $\begin{array}{r}10 \\
1\end{array}$ & $\begin{array}{l}4 \\
0\end{array}$ & $\begin{array}{l}5 \\
0\end{array}$ & $\begin{array}{l}2 \\
0\end{array}$ \\
\hline & 11 & $\begin{array}{l}\mathrm{A} \\
\mathrm{C}\end{array}$ & $\begin{array}{c}0-22 \\
22-150\end{array}$ & $\begin{array}{l}\mathrm{pl} \\
\mathrm{pl}\end{array}$ & $\begin{array}{l}\text { FS } \\
\text { MS }\end{array}$ & $\begin{array}{l}5 \\
0\end{array}$ & $\begin{array}{l}4 \\
1\end{array}$ & $\begin{array}{l}6 \\
1\end{array}$ & $\begin{array}{l}22 \\
73\end{array}$ & $\begin{array}{l}58 \\
23\end{array}$ & $\begin{array}{l}5 \\
1\end{array}$ & $\begin{array}{l}2 \\
1\end{array}$ & $\begin{array}{l}3 \\
0\end{array}$ & $\begin{array}{l}0 \\
0\end{array}$ \\
\hline & 5 & $\begin{array}{l}\mathrm{Ap} \\
\mathrm{Et} \\
\mathrm{Bt} \\
\mathrm{C}\end{array}$ & $\begin{array}{c}0-31 \\
31-56 \\
56-102 \\
102-150\end{array}$ & $\begin{array}{l}\text { gz } \\
\text { pyi } \\
\text { ipy } \\
\text { gpyi }\end{array}$ & $\begin{array}{l}\mathrm{L} \\
\mathrm{SiL} \\
\mathrm{SiC} \\
\mathrm{SiCL}\end{array}$ & $\begin{array}{l}0 \\
0 \\
0 \\
0\end{array}$ & $\begin{array}{l}5 \\
0 \\
0 \\
0\end{array}$ & $\begin{array}{l}6 \\
1 \\
0 \\
0\end{array}$ & $\begin{array}{r}10 \\
2 \\
0 \\
0\end{array}$ & $\begin{array}{r}18 \\
8 \\
6 \\
7\end{array}$ & $\begin{array}{l}8 \\
1 \\
1 \\
1\end{array}$ & $\begin{array}{r}18 \\
2 \\
2 \\
2\end{array}$ & $\begin{array}{l}24 \\
60 \\
41 \\
50\end{array}$ & $\begin{array}{l}11 \\
26 \\
50 \\
40\end{array}$ \\
\hline & 6 & $\begin{array}{l}\mathrm{Ap} \\
\mathrm{Et} \\
\mathrm{Bt} \\
\mathrm{Cg}\end{array}$ & $\begin{array}{l}0-33 \\
33-58 \\
58-90 \\
90-150\end{array}$ & $\begin{array}{l}\text { gp } \\
\text { pyg } \\
\text { iz } \\
\text { ic } \\
\end{array}$ & $\begin{array}{l}\mathrm{SL} \\
\mathrm{SiL} \\
\mathrm{C} \\
\mathrm{HC}\end{array}$ & $\begin{array}{l}0 \\
0 \\
0 \\
0\end{array}$ & $\begin{array}{l}9 \\
1 \\
0 \\
0\end{array}$ & $\begin{array}{l}9 \\
3 \\
1 \\
0\end{array}$ & $\begin{array}{r}18 \\
6 \\
1 \\
0\end{array}$ & $\begin{array}{r}20 \\
17 \\
9 \\
8\end{array}$ & $\begin{array}{r}13 \\
13 \\
5 \\
2\end{array}$ & $\begin{array}{c}15 \\
26 \\
11 \\
3\end{array}$ & $\begin{array}{l}10 \\
27 \\
18 \\
21\end{array}$ & $\begin{array}{c}6 \\
7 \\
55 \\
66 \\
\end{array}$ \\
\hline \multirow[t]{4}{*}{$\begin{array}{l}\text { Footslope / } \\
\text { toeslope }\end{array}$} & 3 & $\begin{array}{l}\mathrm{A} \\
\mathrm{C}\end{array}$ & $\begin{array}{c}0-68 \\
68-150\end{array}$ & $\begin{array}{l}\text { pg } \\
\text { gpyi }\end{array}$ & $\begin{array}{l}\text { LFS } \\
\text { SiCL }\end{array}$ & $\begin{array}{l}0 \\
0\end{array}$ & $\begin{array}{l}3 \\
0\end{array}$ & $\begin{array}{l}6 \\
0\end{array}$ & $\begin{array}{c}16 \\
1\end{array}$ & $\begin{array}{c}43 \\
6\end{array}$ & $\begin{array}{l}7 \\
7\end{array}$ & $\begin{array}{r}5 \\
18\end{array}$ & $\begin{array}{l}16 \\
36\end{array}$ & $\begin{array}{c}4 \\
32\end{array}$ \\
\hline & 7 & $\begin{array}{l}\text { Ap } \\
\text { A2 } \\
\text { A3 } \\
\text { G }\end{array}$ & $\begin{array}{c}0-30 \\
30-56 \\
56-107 \\
107-150\end{array}$ & $\begin{array}{l}\text { gp } \\
\text { pyi } \\
\text { pyi } \\
\text { ps }\end{array}$ & $\begin{array}{l}\text { FSL } \\
\text { SiL } \\
\text { SiL } \\
\text { COS }\end{array}$ & $\begin{array}{c}0 \\
0 \\
0 \\
45\end{array}$ & $\begin{array}{r}9 \\
0 \\
0 \\
17\end{array}$ & $\begin{array}{r}11 \\
2 \\
0 \\
29\end{array}$ & $\begin{array}{r}12 \\
2 \\
0 \\
27\end{array}$ & $\begin{array}{l}26 \\
18 \\
13 \\
11\end{array}$ & $\begin{array}{r}13 \\
9 \\
14 \\
3\end{array}$ & $\begin{array}{c}13 \\
19 \\
28 \\
2\end{array}$ & $\begin{array}{r}10 \\
33 \\
25 \\
4\end{array}$ & $\begin{array}{r}6 \\
17 \\
20 \\
7\end{array}$ \\
\hline & 4 & $\begin{array}{l}\mathrm{A} 1 \\
\mathrm{~A} 2 \\
2 \mathrm{C}\end{array}$ & $\begin{array}{c}0-30 \\
30-110 \\
110-150\end{array}$ & $\begin{array}{l}\text { ps } \\
\text { pl } \\
\text { gpyi }\end{array}$ & $\begin{array}{l}\text { FS } \\
\text { FS } \\
\text { SiCL }\end{array}$ & $\begin{array}{l}0 \\
0 \\
0\end{array}$ & $\begin{array}{l}2 \\
3 \\
0\end{array}$ & $\begin{array}{r}8 \\
10 \\
0\end{array}$ & $\begin{array}{r}24 \\
25 \\
0\end{array}$ & $\begin{array}{c}47 \\
48 \\
6\end{array}$ & $\begin{array}{l}7 \\
6 \\
6\end{array}$ & $\begin{array}{r}4 \\
4 \\
17\end{array}$ & $\begin{array}{c}8 \\
4 \\
42\end{array}$ & $\begin{array}{r}0 \\
0 \\
29\end{array}$ \\
\hline & 10 & $\begin{array}{l}\text { A1 } \\
\text { A2 } \\
\text { A3 }\end{array}$ & $\begin{array}{c}0-30 \\
30-110 \\
110-150\end{array}$ & $\begin{array}{l}\text { pl } \\
\text { pl } \\
\text { ps }\end{array}$ & $\begin{array}{l}\text { FS } \\
\text { FS } \\
\text { FS }\end{array}$ & $\begin{array}{r}13 \\
12 \\
9\end{array}$ & $\begin{array}{l}9 \\
8 \\
5\end{array}$ & $\begin{array}{l}14 \\
13 \\
12\end{array}$ & $\begin{array}{l}19 \\
24 \\
20\end{array}$ & $\begin{array}{l}41 \\
36 \\
43\end{array}$ & $\begin{array}{r}8 \\
10 \\
10\end{array}$ & $\begin{array}{l}3 \\
3 \\
4\end{array}$ & $\begin{array}{l}6 \\
5 \\
5\end{array}$ & $\begin{array}{l}0 \\
1 \\
1\end{array}$ \\
\hline
\end{tabular}




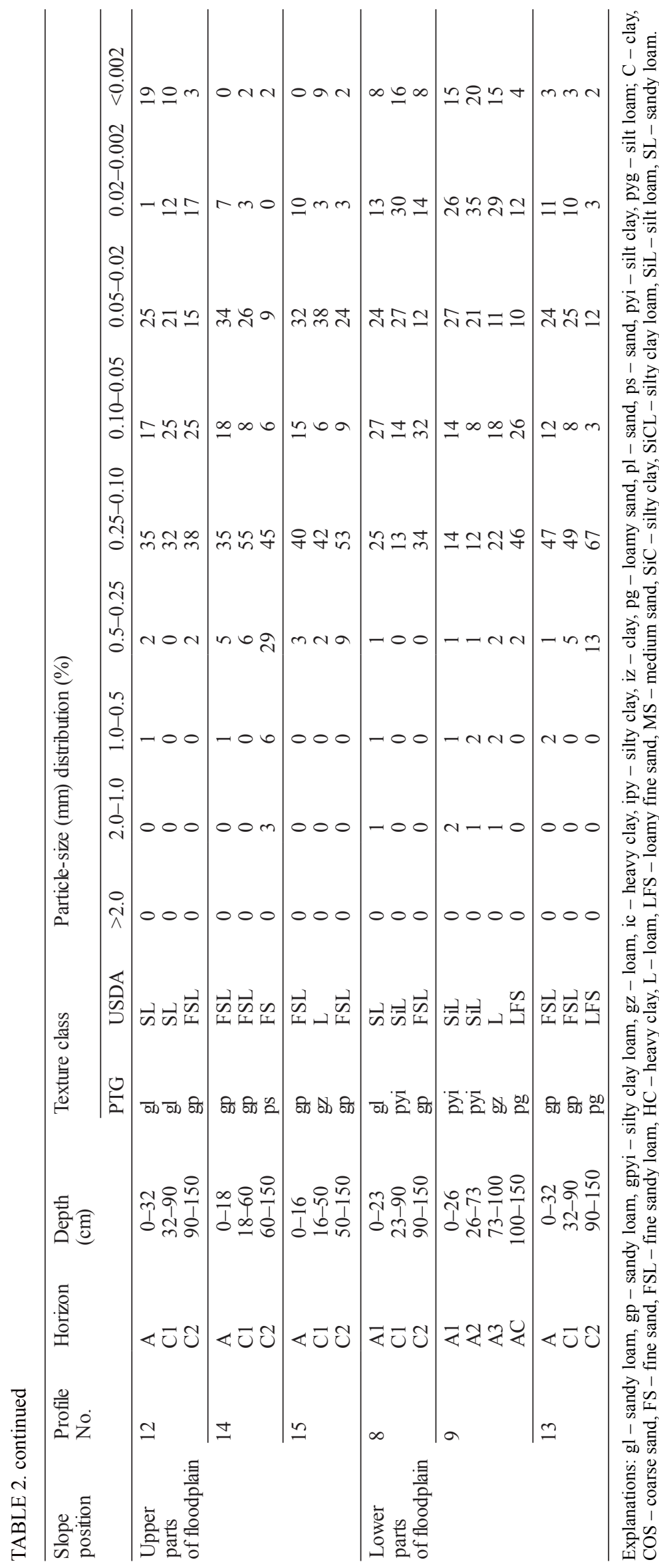

different texture classes (profiles 8, 9 and $13)$. Fine and very fine sand $(28-70 \%)$, as well as silt fractions (15-56\%) prevailed in these soils. They also contained substantial amount of clay fraction $(9,4 \%$ in average, $\max 20 \%$ ).

For the analysis of PSD in the studied soil transects, PSD histograms for humus horizons of eroded soils, parent material, colluvial and alluvial material were used (Fig. 3). In the transect A humus horizons and parent materials of soils were characterized by unimodal particle-size distribution (Fig. 3A). Whereas colluvial horizons had bimodal distribution, with enrichment in clay fraction. The PSD in soil horizons from transects $\mathrm{B}$ and $\mathrm{C}$ was bimodal (Fig. 3B and 3C). In the first one alluvial deposits were more enriched in fine silt fraction $(0.02-0.002 \mathrm{~mm})$, and colluvial in fine sand fraction $(0.25-0.10 \mathrm{~mm})$ in relation to humus horizon of eroded soils. In the last transect the first mode was fine sand $(0.25-0.10 \mathrm{~mm})$ and the second - coarse silt $(0.05-0.02 \mathrm{~mm})$. Alluvial deposits were enriched in coarse silt.

\section{Sedimentological and granulometric indices}

Humus horizons of rusty soils and arenosols had average $\mathrm{Mz}$ amounting to 162.0-182.6 $\mu \mathrm{m}$. Mean diameter was increasing with depth as a result of soilforming process of rusty soils and physical and chemical weathering (Table 3 ). In clayilluvial soils, in A horizons, average mean diameter amounted to $78.8 \mu \mathrm{m}$ and was decreasing down the soil profile, reaching $2.0 \mu \mathrm{m}$ in parent material. This relationship may result from pedogenic processes, but primarily from the lithological discontinuity of glacial and post-glacial parent materials (Musztyfaga and Kabała 2015). Standard deviation index in humus horizons of eroded soils amounted to 1.2 (arenosols), 1.6 (rusty soils) and 3.0 (soil lessives). It suggests that eroded soil material located at the summit and midslope of the valley was poorly and very poorly sorted. Similar values of standard deviation were noted in deeper soil horizons. Only in parent material of arenosols, fluvioglacial sands were medium sorted $\left(\delta_{1}=0.7\right)$ (Table 3$)$. The average 
A

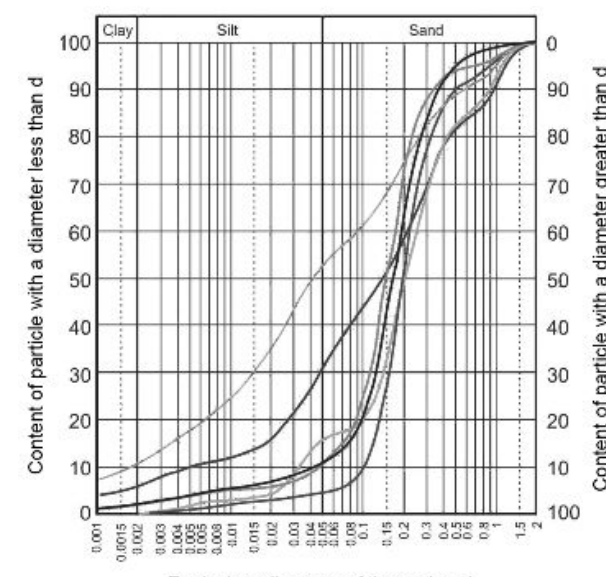

Equivalent diameter of the grain - $d$

B

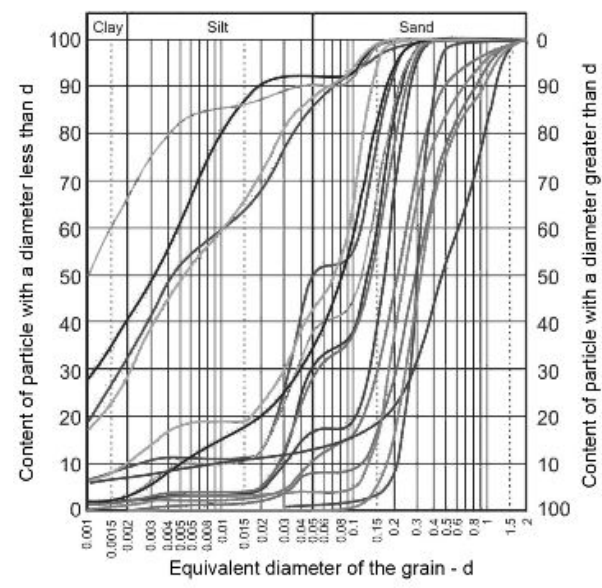

$\mathrm{C}$

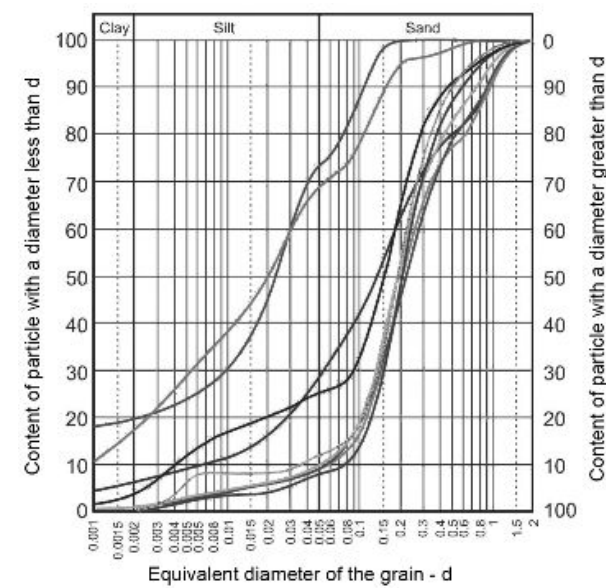

D

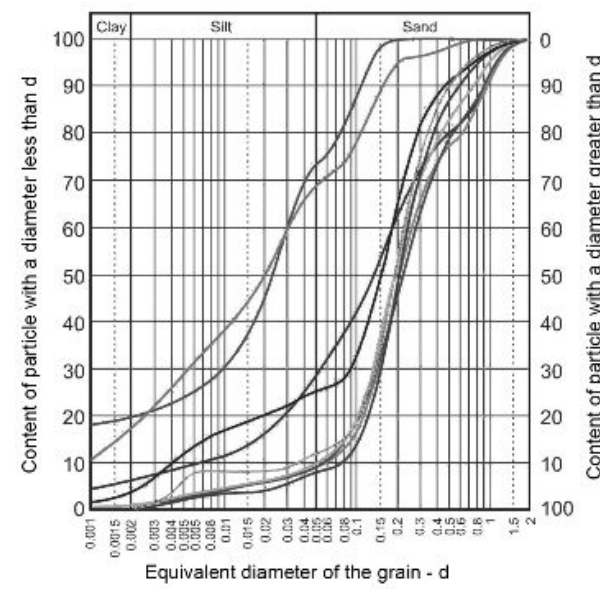

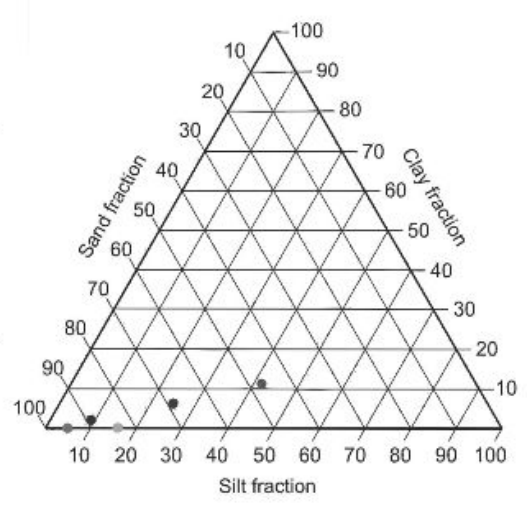
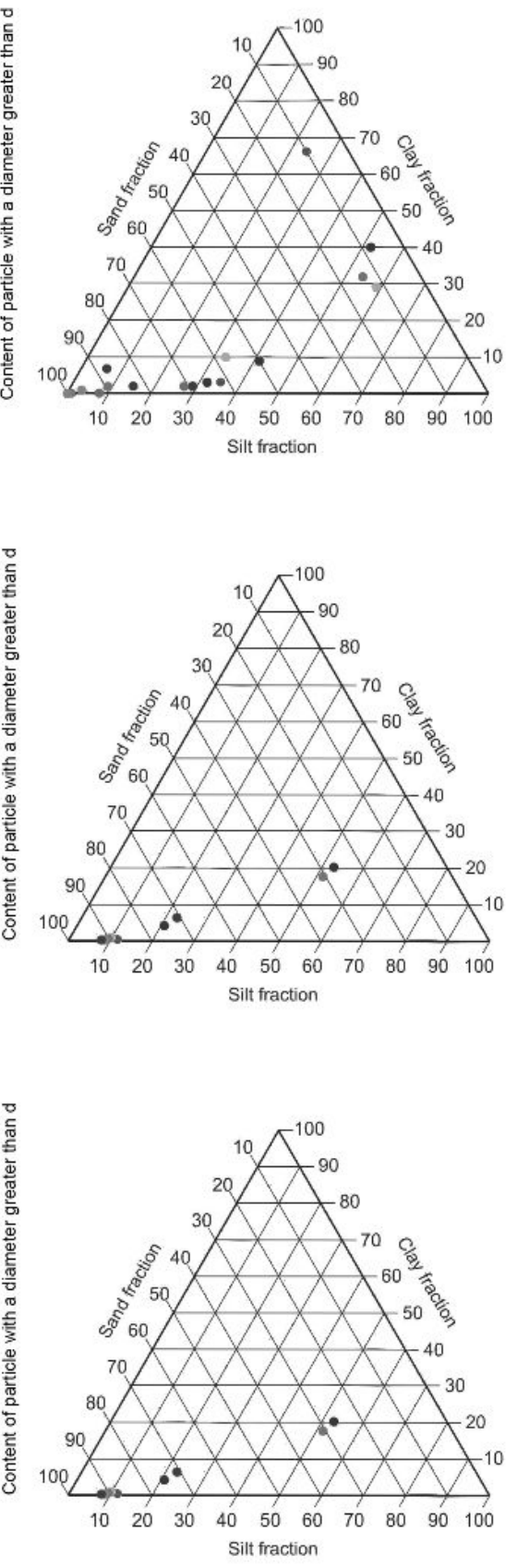

FIGURE 2. Cumulative curves and graphical display of the texture of soils under study. Explanation: A - humus horizons of eroded soils: clay-illuvial soils, rusty soils and arenosols,

$\mathrm{B}$ - parent material,

C - colluvial horizons,

D - alluvial horizons 

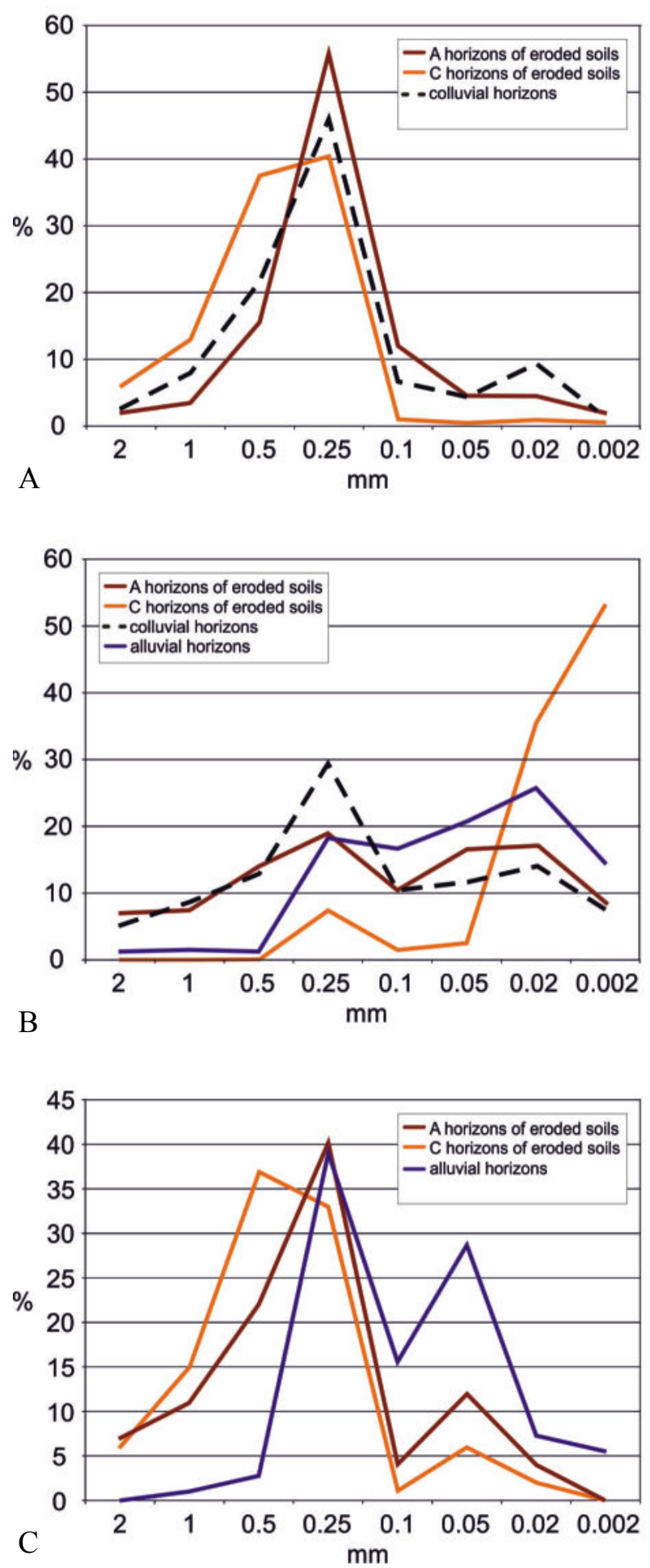

FIGURE 3. Histograms of texture of different soil materials in three transects in the Eyna River valley. Explanations: A- Knopin, $\mathrm{B}$ - Smolajny, $\mathrm{C}$ - Łaniewo

skewness index $\left(\mathrm{Sk}_{1}\right)$ ranged from -0.1 to 0.2 in studied soils. It proves symmetrical (mainly in rusty soils and arenosols) and fine skewed (upper horizons of clay-illuvial soils) PSD. Eroded soils had very lep- tokurtic $\left(\mathrm{K}_{\mathrm{g}}=1.5-1.9\right.$ in average $)$ and leptokurtic $\left(\mathrm{K}_{\mathrm{g}}=\right.$ 1.1-1.4 in average) granulometric distribution (Table 3).

Described sedimentological indices are typical of glacial tills and fluvioglacial sands, from which studied soils were formed (Bieniek 2013, Kobierski 2010, Różański 2010, Zagórski 1996).

Average mean diameter in colluvial soil material, amounted to $146.1 \mu \mathrm{m}$ (range 10.8-248.1 $\mu \mathrm{m}$ ) and it was significantly lower than in eroded sandy soils in humus horizons (Table 3). The colluvial material was very poorly sorted with average standard deviation index of 2.3. Similar values of $\ddot{a}_{1}$ were stated in parent material underlying colluvial horizons. The material accumulated at footslope / toeslope had fine skewed asymmetric $\left(\mathrm{Sk}_{1}=0.2\right)$ and very leptokurtic $\left(\mathrm{K}_{\mathrm{g}}=1.6\right)$ particle-size distribution. Values of analyzed indices suggest typical lower mean grain diameter and similar sorting degree of colluvial deposits in comparison with original formations (Smolska 2005, Sowiński 2014, Sowiński et al. 2015). Values of $K_{g}$ in colluvial, glacial and fluvioglacial deposits have similar dynamics in sedimentological environment.

The alluvial material accumulated in upper and lower parts of floodplain, had similar sedimentological features. Average mean diameter ranged from $40.5 \mu \mathrm{m}$ in lower parts to $53.1 \mu \mathrm{m}$ in upper parts. The soil material in humus horizons of alluvial soils was very poorly sorted $\left(\delta_{1}=2.4-2.9\right.$ in average $)$ and had very fine skewed asymmetric $\left(\mathrm{Sk}_{1}=0.4-0.5\right)$ and very leptokurtic $\left(\mathrm{K}_{\mathrm{g}}=1.7-1.8\right)$ particle-size distribution. The parent deposits (fluvioglacial origin) of alluvial soils were better sorted (Table 3).

In order to determine genetic homogeneity or heterogeneity of soil material, granulometric indices were calculated according to Kowalkowski and Prusinkiewicz (1963). These indices determine quantitative relations between fractions of sand and silt. The deposits accumulated in homogenous sedimentological environment have similar indices, whereas the differences in indices suggest heterogeneous sedimentological environment. The granulometric indices had various values, reflecting the heterogeneity of soil material (Table 3). The values of granulometric A index in humus horizons amounted to: 2.8-3.3 (rusty soils and arenosols), 1.5 (clay-illuvial soils), 3.0 (colluvial soils) and 12.6-22.0 (alluvial soils). It was well manifested by a high proportion of fine sand subfraction in alluvial soils. The mentioned index had similar relations but lower values in parent material of studied soils (Table 3). In humus horizons of rusty soils and arenosols the AE indices had similar values, which suggests similar rate of pedogenic processes in these soils. In their parent materials the A, C and D indices had similar values but $\mathrm{B}$ and $\mathrm{E}$ indices very different (prevalence of fine 
and very fine sand). It proves the differentiation of sedimentological conditions in soil formations of the same origin. In clay-illuvial soils the values of analysed indices were typical for these soil units and related to the lithological discontinuity (Musztyfaga and Kabała 2015). The most homogenous soil formation was found in the colluvial horizons. The values of A-D indices amounted to 3.0-4.8, and of E - to 8.0. The most heterogenous soil formations were alluvial deposits (Table 3). They were enriched in very fine and fine sand $(0.25-0.05 \mathrm{~mm})$ in relation to coarser sand fraction $(2.0-0.5 \mathrm{~mm})$.

\section{Soil particle-size distribution in different slope positions in the river valley}

A multivariate method of PCA was applied in order to assess the relation between content of the soil fractions and environmental variables such as slope position and depth of A horizon (Fig. 4A). The cumulative percentage variance explained by PCA1 and PCA2 as much as $88.3 \%$ of soil-environment relationship. The first axis (PCA1) explained 76.0\% of the total variance of the original data set. Most of the variance contained in PCA1 was negatively associated with the environmental variables. However, it was positively correlated with the depth of A horizon and subsequently to the content of silt and clay. PCA2 explained $14.5 \%$ of the variance. The source of variability of content of coarse silt $(0.05-0.02 \mathrm{~mm})$ was the slope position.

Figure 4B summarizes the obtained results and shows clear relationship between soil particle-size distribution and slope position in the studied river valley. The high variability of the PSD within the studied soil transects was recorded. It confirmed the general observations for soils of young glacial landscapes conducted by other authors (Bieniek 1997, Smolska 2005, Smólczyński et al. 2013, Sowiński 2014, Sowiński et al. 2015, Świtoniak 2014). The A horizons in soils located at the summit/midslope and footslope / toeslope had the highest amounts of sand fractions. Gravel fractions were deposited only in soils in the summit/midslope and footslope/toeslope. While significant increase in the share of finer fractions in A horizons in soils in the upper and lower parts of the floodplain as well as in other parts of the slope was noted. As stated by Sklar et al. (2016), Smólczyński et al. (2013) and Smólczyński et al. (2015), colluvial and alluvial processes may overlap on the edge of river valley. It may suggest that slope processes had significant influence on PSD of studied alluvial materials, mainly due to enrichment in silt and clay fractions (Attal et al. 2015, Rienzi et al. 2013).
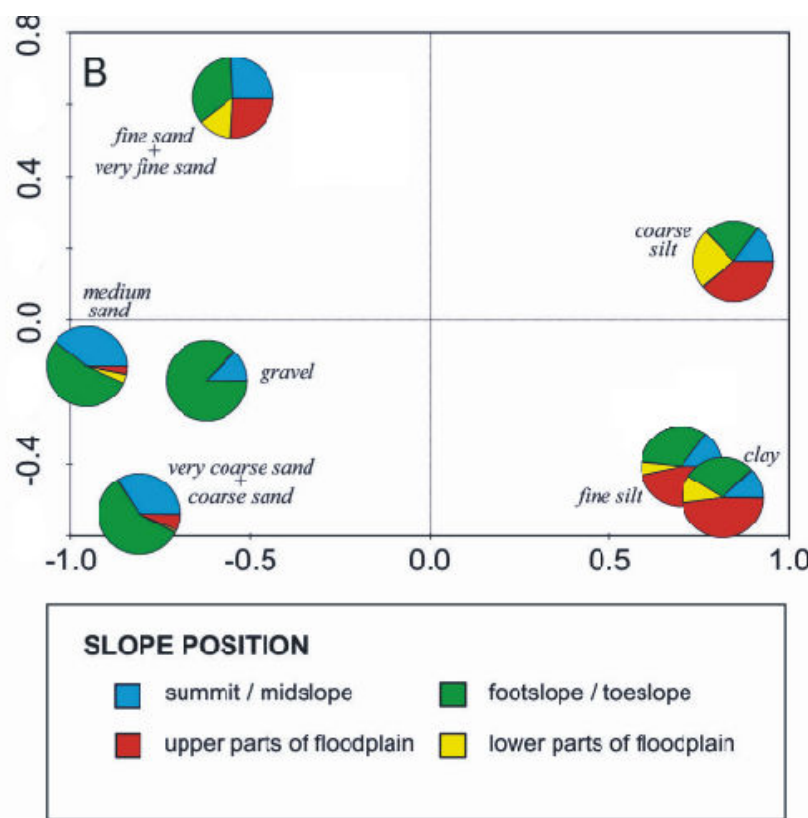

FIGURE 4. Ordination diagram of PCA computed for the soil fractions in A horizons and environmental variables. Pie charts denote the shares of the fractions in the slope position defined for the Eyna River valley (explanation: see Table 2) 


\begin{tabular}{|c|c|c|c|c|c|c|c|c|c|c|c|}
\hline \multirow{3}{*}{$\begin{array}{l}\text { Slope } \\
\text { position }\end{array}$} & \multirow{3}{*}{$\begin{array}{l}\text { Profile } \\
\text { No } \\
\text {. }\end{array}$} & \multirow[t]{3}{*}{ Horizon } & \multicolumn{4}{|c|}{ Sedimentological indices } & \multicolumn{5}{|c|}{ Granulometric indices } \\
\hline & & & $\mathrm{Mz}$ & $\delta_{1}$ & $\mathrm{Sk}_{1}$ & $\mathrm{~K}_{\mathrm{g}}$ & A & B & $\mathrm{C}$ & $\mathrm{D}$ & $\mathrm{E}$ \\
\hline & & & \multicolumn{2}{|l|}{$(\mu \mathrm{m})$} & \multicolumn{2}{|l|}{ (phi) } & & & & & \\
\hline \multirow{17}{*}{$\begin{array}{l}\text { Summit / } \\
\text { midslope }\end{array}$} & \multirow[t]{6}{*}{1.16} & A & $162.0 *$ & 1.6 & 0.2 & 1.9 & & 11.3 & 4.0 & & \\
\hline & & & $142.7-182.1^{*}$ & $1.4-1.7$ & $0.2-0.2$ & $1.5-2.2$ & $1.8-4.8$ & $3.6-19.0$ & $2.0-5.9$ & $1.7-5.1$ & $6.0-27.7$ \\
\hline & & $\mathrm{Bv}$ & 232.6 & 1.3 & 0.0 & 1.7 & 3.3 & 7.0 & & & 11.1 \\
\hline & & & $134.5-330.6$ & $1.3-1.3$ & $-0.1-0.1$ & $1.5-1.8$ & $1.0-5.5$ & $3.0-11.0$ & $1.1-7.1$ & $0.8-5.2$ & $6-16.2$ \\
\hline & & $\mathrm{C}$ & 274.4 & 1.1 & -0.1 & 1.5 & 1.3 & 3.4 & 1.3 & 1.1 & \\
\hline & & & 255.4-293.2 & $0.9-1.3$ & $-0.2-0.1$ & $1.3-1.6$ & $0.9-1.7$ & $2.2-4.6$ & $0.9-1.7$ & $0.8-1.3$ & $4.7-7.4$ \\
\hline & \multirow[t]{4}{*}{2,11} & A & 182.6 & 1.2 & 0.1 & 1.9 & 2.8 & 11.8 & 3.2 & 2.7 & 17.6 \\
\hline & & & $160.3-204.8$ & $1.0-1.4$ & $-0.1-0.3$ & $1.7-2.1$ & $2.6-2.9$ & $9.7-13.8$ & $2.9-3.4$ & $2.3-3.0$ & $14.2-21.0$ \\
\hline & & $\mathrm{C}$ & 318.6 & 0.7 & -0.1 & & & 12.6 & 0.5 & & \\
\hline & & & 291.4-345.7 & $0.4-0.9$ & $-0.2-0.1$ & $1.2-1.2$ & $0.3-0.7$ & $2.1-23.0$ & $0.3-0.7$ & $0.3-0.5$ & $5.1-97.0$ \\
\hline & \multirow[t]{7}{*}{5,6} & Ap & 78.8 & 3.0 & 0.2 & 1.1 & 1.5 & 2.6 & 2.2 & & \\
\hline & & & $37.8-119.7$ & $2.7-3.2$ & $0.1-0.2$ & $1.0-1.2$ & $1.1-1.8$ & $2.2-3.0$ & $1.8-2.6$ & $1.8-2.8$ & $5.7-6.0$ \\
\hline & & Et & 18.3 & & 0.2 & & & & & & 11.5 \\
\hline & & & 4.4-32.1 & $2.5-2.7$ & $0.1-0.2$ & $1.1-1.6$ & $2.8-4.0$ & $5.7-8.0$ & 4.6-5.0 & $3.7-4.2$ & $11.0-12.0$ \\
\hline & & $\mathrm{Bt}$ & & 3.3 & & & 9.0 & 9.0 & 14.0 & & 15.0 \\
\hline & & $\mathrm{C}$ & & 2.8 & -0.1 & & - & - & - & - & - \\
\hline & & & $1.2-2.7$ & $2.7-2.8$ & $-0.2-0.1$ & $1.2-1.4$ & & & & & \\
\hline \multirow{4}{*}{$\begin{array}{l}\text { Footslope / } \\
\text { toeslope }\end{array}$} & \multirow{4}{*}{$\begin{array}{l}3,7,4, \\
10\end{array}$} & A & 146.1 & & & & & & & & \\
\hline & & & $10.8-248.1$ & $1.3-4.1$ & $0.1-0.6$ & $0.8-2.3$ & $1.5-9.0$ & $2.4-9.0$ & $1.9-13.5$ & $1.3-11.5$ & $4.6-14.5$ \\
\hline & & $\mathrm{C}$ & 123.3 & 2.6 & 0.1 & 1.4 & 3.2 & & 6.8 & 15.7 & \\
\hline & & & $5.6-358.5$ & $2.5-2.7$ & $-0.2-0.5$ & $0.8-2.4$ & $0.4-6.0$ & $0.4-0.4$ & $0.5-13.0$ & $0.3-31.0$ & $1.4-1.4$ \\
\hline \multirow{4}{*}{$\begin{array}{l}\text { Upper } \\
\text { parts of } \\
\text { floodplain }\end{array}$} & \multirow{4}{*}{$\begin{array}{l}12,14, \\
15\end{array}$} & A & 53.1 & & 0.4 & 1.7 & 12.6 & 35.0 & & 23.1 & 56.0 \\
\hline & & & $19.2-70.7$ & $1.3-4.4$ & $0.1-0.7$ & $0.9-2.9$ & $7.0-17.5$ & $35.0-35.0$ & $10.6-26.0$ & $14.5-29.0$ & $54.0-58.0$ \\
\hline & & $\mathrm{C}$ & 88.4 & 1.7 & 0.4 & 1.2 & 11.3 & 7.5 & 14.9 & 21.6 & 13.3 \\
\hline & & & $31.8-195.2$ & $1.2-2.4$ & $0.2-0.7$ & $0.7-1.6$ & $1.6-21.0$ & $7.5-7.6$ & $1.8-31.5$ & $1.7-43.0$ & $13.3-13.3$ \\
\hline \multirow{4}{*}{$\begin{array}{l}\text { Lower } \\
\text { parts of } \\
\text { floodplain }\end{array}$} & \multirow[t]{4}{*}{$8,9,13$} & A & 40.5 & 2.9 & 0.5 & & 22.0 & 15.9 & 35.8 & 26.8 & 28.7 \\
\hline & & & $12.1-70.9$ & $1.7-4.2$ & $0.3-0.6$ & $1.2-2.6$ & $11.0-47.0$ & $6.0-25.0$ & $20.0-59.0$ & $12.8-41.0$ & $10.5-53.0$ \\
\hline & & $\mathrm{C}$ & 87.4 & 1.6 & 0.9 & 1.6 & & - & 8.4 & 11.4 & - \\
\hline & & & $47.2-122.0$ & $1.1-2.1$ & $0.6-1.6$ & $1.1-1.8$ & $5.2-9.8$ & & $5.4-11.4$ & $6.3-16.4$ & \\
\hline
\end{tabular}




\section{CONCLUSIONS}

1. The analyzed soils were characterized by various sedimentological indices. The soil formations were very poorly and poorly sorted, had different values of skewness (symmetrical, fine and very fine skewed) and kurtosis (mainly very leptokurtic). As a result of denudation processes the mean grain diameter decreased from the summit towards lower parts of the floodplain.

2. The analysis of granulometric indices revealed that colluvial deposits were the most homogenous and alluvial formations were the most heterogenous. It might be related to overlapping lithological and pedogenic factors on the slope.

3. The results of the statistical analysis showed a positive correlation of the amounts of clay and silt fractions with depth of A horizons of analyzed soils. The main factor responsible for variability of these fractions was the position on the slope.

\section{REFERENCES}

Attall M., Muld S.M., Hurst M.D., Weigman B., Yoo K., Taylor M., 2015. Impact of change in erosion rate and landscape steepness on hillslope and fluvial sediments grain size in the Feather River basin (Sierra Nevada, California). Earth Surface Dynamics 3: 201-222.

Bittelli M., Campbell G.S., Flury M., 1999. Characterization of particle-size distribution in soils with a fragmentation model. Soil Science Society of America Journal 63: 788-792.

Bieniek A., 2013. Soils of inner outwash plains in the north-eastern Poland. Wydawnictwo UWM, Olsztyn, 184: 115 pp. (in Polish with English summary).

Bieniek B., 1997. Properties and development of deluvial soils of the Mazurian Lakeland. Acta Acad. Agricult. Tech. Olst., Agricultura, Supplementum B 64: 80 pp. (in Polish with English summary).

BJB software house. 2010. Siewca 3.0 (software). Poznań.

Booth A.M., Roering J.J., Rempel A.W., 2013. Topographic signatures and a general transport law for deep-seated landslides in a landscape evolution model Journal of Geophysical Research: Earth Surface 118: 1-22.

Brogowski Z., 1990. An attempt of calculation of some physical properties of soils on the basis of granulometric analysis. Roczniki Gleboznawcze - Soil Science Annual 41(3/4): 1728 (in Polish with English summary).

Brogowski Z., Kwasowski W., 2014. Contribution of granulometric fractions in phosphorus distribution in old alluvial soil. Soil Science Annual 65(4): 150-155.

Brogowski Z., Kwasowski W., 2015. An attempt of using soil grain size in calculating the capacity of water unavailable to plants. Soil Science Annual 66(1): 21-28.

Brogowski Z., Kwasowski W., Madyniak R., 2014. Calculating particle density, bulk density, and total porosity of soil based on its texture. Soil Science Annual 65(4): 139-149.

Folk R.L., Ward W., 1957. Brazos River Bar: A study in the significance of grain size parameters. Journal of Sedimentary Petrology 27: 3-26.
Glińska-Lewczuk K., Bieniek A., Sowiński P., Obolewski K., Burandt P., Timifte C.M., 2014. Variability of zinc content in soils in a postglacial river valley - a goechemical landscape approach. Journal of Elementology 19(1): 361-376.

IUSS Working Group WRB, 2015. Word Reference Base for Soil Resources 2014 - an international system for soil classification, first update 2015. Word Soil Resources Reports 106. FAO, Rome: $181 \mathrm{pp}$.

Jonczak J., Kowalkowski A., 2013. Genesis, spatial variability and properties of the polygenetic soils of Jarosławianka catchment. [In:] Środowisko glebotwórcze i gleby dolin rzecznych. J. Jończak, W. Florek (Eds). Wyd. Naukowe Bogucki, Poznań: 4156 (in Polish with English summary).

Kabała C., Marzec M., 2010. Vertical and spatial diversity of grain-size distribution in Luvisols developed from loess in south-western Poland. Roczniki Gleboznawcze - Soil Science Annual 61(3): 52-64 (in Polish with English summary).

Kabała C., Świtoniak M., Charzyński P., 2016. Correlation between the Polish Classification System (2011) and international soil classification system World Reference Base for Soil Resources (2015). Soil Science Annual 67(2): 88-100.

Kobierski M., 2010. Texture of different types of soils formed from glacial till in the aspect of PTG 2008 classification system. Roczniki Gleboznawcze - Soil Science Annual 61(3): 65-74 (in Polish with English summary).

Kowalkowski A., Prusinkiewicz Z., 1963. Granulometric numeral indices as indicators of uniformity in Pleistocene sedimental strata. Roczniki Gleboznawcze - Soil Science Annual 13 (supl.): 159-162 (in Polish with English summary).

Musztyfaga E., Kabała C., 2015. Lithological discontinuity in Glossic Planosols (Albeluvisols) of Lower Silesia (SW Poland). Soil Science Annual 66(4): 180-190.

Mycielska-Dowgiałło E., 1980. Wstęp do sedymentologii. WSP, Kielce: 178 pp. (in Polish).

Piaścik H., Sowiński P., Lemkowska B. 2004. Physical-geographical conditions in the evolution of river valleys and accumulated formations in the Mazurian Lakeland landscape. [In:] Bliskie naturze kształtowanie dolin rzecznych. T. Heese, W. Puchalski (Eds). Monografia Wydziałuu Budownictwa i Inżynierii Środowiska, Wydawnictwo Uczelniane Politechniki Koszalińskiej, Koszalin, 103: 84-90 (in Polish with English summary).

Polish Soil Classification, 2011. Roczniki Gleboznawcze-Soil Science Annual 62(3): 1-193 (in Polish with English summary).

Prusinkiewicz Z., Proszek P., 1990. "Texture" - the program of computer interpretation of results of soil particle size analysis. Roczniki Gleboznawcze - Soil Science Annual 41(3/4): 5-16 (in Polish with English summary).

Prusinkiewicz Z., Konus L., Kwiatkowska A., 1994. Classification of soil texture and related problems. Roczniki Gleboznawcze - Soil Science Annual 45(3/4): 5-20 (in Polish with English summary).

Polskie Towarzystwo Gleboznawcze, 2009. Particie size distribution and textural classes in soils and mineral materials classification of Polish Society of Soil Science 2008. Roczniki Gleboznawcze - Soil Science Annual 60(2): 6-15.

Racinowski R., Szczypek T., Wach J., 2001. Prezentacja i interpretacja wyników badań uziarnienia osadów czwartorzędowych. Wydawnictwo UOE, Katowice: 146 pp. (in Polish).

Rienzi E.A., Fox J.F., Grove J.H., Matocha C.J., 2013. Interrill erosion in soils with different land uses: The kinetic energy 
wetting effect on temporal particle size distribution. Catena 107: 130-138.

Różański S., 2010. Texture of different types of soils with regard to their origin and changes in textural classification. Roczniki Gleboznawcze - Soil Science Annual 61(3): 100-110 (in Polish with English summary).

Ryżak M., Bartmiński P., Bieganowski A., 2009. Methods for determination of particle size distribution of mineral soils. Acta Agrophysica, Rozprawy i Monografie 4(175): 105 pp. (in Polish with English summary).

Schoeneberger P.J., Wysocki D.A., Benham E.C., 2012. Field book for describing and sampling soils, Version 3.0. Soil Survey Staff. National Soil Survey Center, Lincoln, NE: 266 pp.

Sklar L.S., Riebe C.S., Marshall J.A., Genett J., Leclere S., Lukens C., Merces V., 2016. The problem of predicting the size distribution of sediment supplied by hillslopes to rivers. Geomorphology, DOI: 10.1016/j.geomorph. 2016.05.005.

Smolska E., 2005. Slope wash processes in late glacial area on example of Suwałki Lake District, Wydawnictwo Uniwersytetu Warszawskiego (in Polish with English summary).

Smólczyński S., Orzechowski M., Lemkowska B., 2013. Sequences and properties of soils in river valleys in young glacial landscape of north-eastern Poland. [In:] Środowisko glebotwórcze i gleby dolin rzecznych. J. Jończak, W. Florek (Eds). Wyd. Naukowe Bogucki, Poznań: 123-133 (in Polish with English summary).

Smólczyński S., Orzechowski M., Kalisz B., 2015. Distribution of elements in soil catenas developed in ice-dammed lake and morainic landscapes in NE Poland. Journal of Elementology 20(2): 417-434.
Sowiński P., 2014. Toposequence and properties of soils in the hilly landscape of Lier (Buskerud Region, south Norway), Polish Journal of Soil Science 47(1): 51-58.

Sowiński P., Orzechowski M., Smólczyński S., Kalisz B., 2015. Particle-size distribution in soils in various ground moraine catenas in the Masurian Lakeland, Polish Journal of Soil Science 48(2): 157-168.

Sowiński P., Glińska-Lewczuk K., Kalisz B., Astel A., 2016. Distribution of heavy metals in soils in postglacial river valley - a geochemical landscape approach. Environmental Engineering and Management Journal 15(6): 1323-1335.

Świtoniak M., 2014. Use of soil profile truncation to estimate influence of accelerated erosion on soil cover transformation in young morainic landscapes, North-Eastern Poland, Catena 116: $173-184$.

Świtoniak M., 2015. Issues relating to classification of colluvial soils in young morainic areas (Chełmno and Brodnica Lake District, northern Poland), Soil Science Annual 66(2): 57-66.

ter Braak C.J.F., Šmilauer P., 2002. CANOCO, Reference manual and CanoDraw for Windows User's guide: Software for Canonical Community Ordination (version 4.5), Microcomputer Power, Ithaca, NewYork.

Zagórski Z., 1996. Granulometric indices of litho- and pedogenic processes in non-uniform soils developed from glacial deposits. Roczniki Gleboznawcze - Soil Science Annual 47(supl.): 125235 (in Polish with English summary).

Zhao P., Ming-An S., Wang T.J., 2011. Multifractal analysais of particle-size distribution of alluvial soils in the dam farmland on the Loess Plateau of China, African Journal of Agricultural Research, 6(18): 4177-4184.

\section{Uziarnienie gleb w krajobrazie mlodoglacjalnym w odniesieniu do ich położenia na stoku w dolinie rzeki Łyny}

Streszczenie: W pracy przedstawiono wpływ położenia gleb na stoku na skład granulometryczny w młodoglacjalnej dolinie rzeki Łyny. Badaniami objęto: gleby rdzawe, arenosole, gleby płowe, gleby deluwialne oraz mady rzeczne występujące w obrębie różnych elementów rzeźby terenu (wierzchowina, środkowa część zbocza, podnóże, terasa zalewowa) w dolinie rzecznej. Celem badań była charakterystyka uziarnienia tych gleb w odniesieniu do procesów litogenicznych i glebotwórczych oraz położenia gleb na stoku. Na podstawie wskaźników sedymentologicznych i granulometrycznych scharakteryzowano środowisko sedymentacyjne oraz stopień jednorodności utworów glebowych. Charakter i siłę powiązań między zawartością poszczególnych frakcji glebowych i czynnikami środowiskowymi (np. umiejscowieniem na stoku) określono przy użyciu analizy głównych składowych (PCA).

Analizowane gleby charakteryzowały się bardzo słabym stopniem wysortowania, różnymi wartościami skośności (rozkład: symetryczny, dodatnie i bardzo dodatnio skośny) oraz spłaszczenia (rozkład bardzo leptokurtyczny). Średnia średnica ziarna w badanych glebach obniżała się od wierzchowiny do terasy zalewowej. Uzyskane wyniki wskazują na dużą dynamikę i energetykę środowiska sedymentacyjnego w środkowym odcinku doliny Łyny. Analiza wskaźników granulometrycznych wykazała, że najbardziej jednorodnymi były utwory deluwialne, zaś niejednorodnymi - aluwialne. Analiza PCA wykazała pozytywną korelację zawartości frakcji iłu i pyłu z głębokością zalegania utworów glebowych. Źródłem zróżnicowania zawartości frakcji pyłu grubego była lokalizacja gleb na stoku. Największe zawartości frakcji piasku stwierdzono w glebach zlokalizowanych na wierzchowinie i u podnóża stoku. Gleby występujące na terasie zalewowej charakteryzowały się natomiast największą zawartością frakcji pyłu i iłu. Analizując poziomy A badanych gleb największe zawartości frakcji piasku stwierdzono w glebach zlokalizowanych na wierzchowinie i u podnóża stoku. Poziomy A gleb położonych na terasie zalewowej charakteryzowały się największą zawartością frakcji pyłu i iłu.

Słowa kluczowe: uziarnienie, wskaźniki sedymentologiczne i granulometryczne, stok 